日本水処理生物学会誌

Jap. J.Water Treat. Biol., Vol.27, No.2, 1991

\title{
中海の底泥表層における硫酸塩還元活性の季節変化
}

\section{Seasonal and vertical sulfate reduction rate of surface sediment in shallow brackish Lake Nakanoumi, Japan}

\author{
森忠洋1) ・ 山下繁樹1) ・ 佐竹研一2) \\ Tadahiro MORI $^{1)}$ - S. YAMASHITA ${ }^{1)} \cdot$ K. SATAKE ${ }^{2)}$
}

\section{島根大学農学部", 国立環境研究所 ${ }^{2)}$}

Dept. of Agricultural Chemistry, Faculty of Agriculture, Shimane University ${ }^{11}$, Chemistry and Physics Division, The National Institute for Environmental Studies ${ }^{2}$

Keywords : sulfate reduction rate, sediment, brackish lake, Nakanoumi, oxydation reduction potential

\begin{abstract}
Sulfate reduction rates of the sediment at the depth of $0-5 \mathrm{~cm}$ were measured for 15 month from September, 1984 to November 1985 in eutrophicated blackish Lake Nakanoumi, Japan.

The sulfate reduction rates were usually high at the surface sediment and decreased with increased depth. The average sulfate reduction rate of the sediment $(0-3 \mathrm{~cm})$ at the central position (St.4) and heavily polluted area Yonago Bay (St.11) was $53.8 \pm 25.0$ and $104.4 \pm 72.1 \mathrm{nmol} \mathrm{day}^{-1} \mathrm{ml}^{-1}$, annual estimated decomposition rate of organic matter was 14.2 and $27.4 \mathrm{~g}^{-\mathrm{cm}^{-2}}$, respectively.
\end{abstract}

\section{Introduction}

Since a stable halocline usually develops at a depth of $3-4 \mathrm{~m}$ in the eutrophicated blackish Lake Nakanoumi, The bottom water below the halocline is always anoxic or anaerobic (Ohtake et al. 1982, Mori et al. 1987). The sediment of the Lake also becomes anoxic or anaerobic where sulfate reducing bacteria (SRB) proliferate because SRB out-compete methane producing bacteria (MPB) in saline environments, especially on the surface of the sediment (Hines \& Buck, 1982 ; Krisjansson et al., 1982 ; Schonheit et al., 1982 ; Banat et al., 1983 ; Winfrey \& Ward, 1983 ; Robinson \& Tiedge 1984). The SRB, therefore, play an important role not only in sulfur cycle but also in the terminal decomposition of organic matter in the sediment of lakes. It is, therefore, of great imporance to estimate the decomposition rate of organic matter from the sulfate reduction rate especially in the sediment of eutrophicated brakish lake.

Anaerobic mineralization of fatty acids such as acetate, propionate and/or L-lactate by SRB was studied by Laanbroek and Pfenning (1981), Widdle \& Pfenning $(1981,1982)$, Sørensen et al. (1981), Brandis -Heep et al. (1983) and Gebhardt et al. (1983).

The annual rate of sulfate reduction and organic carbon decomposition in a coastal marine sediment (Limfjorden, Denmark) was on the average $3.5 \mathrm{~mol}-\mathrm{SO}_{4} \mathrm{~m}^{-2}$ and $84 \mathrm{~g}-\mathrm{C} \cdot \mathrm{m}^{-2}$, respectively (Jørgensen 1977). While the rate of sulfate reduction and organic matter decomposition in a New England salt marsh was $75 \mathrm{~mol} \mathrm{SO}^{2} \cdot \mathrm{m}^{-2} \cdot \mathrm{y}^{-1}$ and $1800 \mathrm{~g}-\mathrm{C} \cdot \mathrm{m}^{-2} \cdot \mathrm{y}^{-2}$, respectively (Howarth \& Teal 1979).

The objectives of this research were to measure the seasonal and vertical changes in sulfate reduction rates of surface sediments and to estimate the decomposition rate of organic matter in shallow and brackish Lake Nakanoumi. The effects of parameters such as temperature, oxidation reduction potential(Eh) and organic matters on the sulfate reduction rate were also investigated.

\section{Method}

\section{Sampling}

Sediments were collected from the center (St. 4) and Yonago Bay (St. 11) in Lake Nakanoumi as indicated in Fig. 1. The characteristics of this lake, including tidal phenomena have been described previously (Ohtake et al., 1982, 1984). 


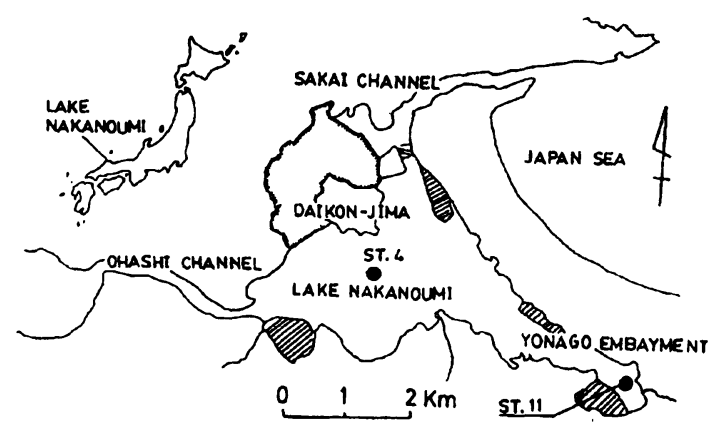

Fig. 1, Map of Lake Nakanoumi showing sampling stations.

St. 4 and St. 11, which are central position and Yonago bay, heavily polluted area in this lake, respectively.

Sediments for determining the sulfate reduction rate were taken every month using a small, handy core sampler which had been developed by Satake(1983) for sampling the surface sediment in shallow lakes. The sampling tube is made of glass of which inner diameter length are $0.8 \mathrm{~cm}$ and $16 \mathrm{~cm}$, respectively.

Sediments for the analysis of ignition loss and sulfate concentration in pore water were sampled by the other core sampler, the tube of which is made of vinyl chloride with an inner diameter and length of $2.4 \mathrm{~cm}$ and $30 \mathrm{~cm}$, respectively. The sediment samples were sealed with rubber stopper and put into an ice box in order to keep the samples at $4^{\circ} \mathrm{C}$ during transportation before analysis.

\section{Sulfate reduction rate}

Munson (1977) and Rosser and Hamilton (1983) developed the simplified method for the determination of sulfides and $\left[{ }^{35} \mathrm{~S}\right]$ sulfate reduction, respectively. In order to absorb hydrogen sulfide, accordion-folded filter paper wicks were dipped in zinc acetate and placed in polypropylene cups suspended below the bung.

In this experiment, the wicks $(3.5 \times 7 \mathrm{~cm}$, Tokyo Roshi Type II) were placed in a $7.0 \mathrm{ml}$ vial (Bottom $\phi 16.5 \times$ H55, Iwaki Glass) in which $1.5 \mathrm{ml}$ of in zinc acetate was added by komagome pipete as shown Fig. 2

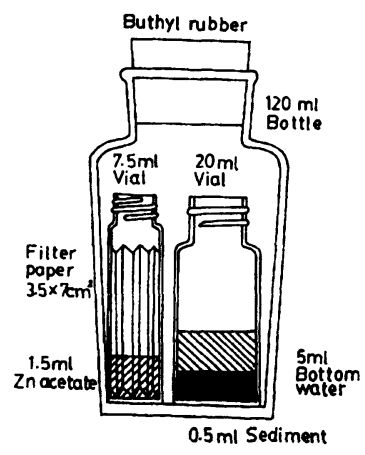

The $7.0 \mathrm{ml}$ vial which contained the wicks dipped in zinc acetate and $20 \mathrm{ml}$ vials (Bottom $\phi 27.5 \times \mathrm{H} 55$, Iwaki Glass) were put into the $120 \mathrm{ml}$ bottle, which was then sealed with a butyl rubber stopper. Two long needles of $10 \mathrm{~cm}$ length were then inserted into the bottle through the butyl rubber stopper for gas exchange. About 20 bottles were put into a desiccator with a diameter of flange $39 \times$ height $31 \mathrm{~cm}$, which was evacuated by pump for about $15 \mathrm{~min}$. Then the nitrogen gas (special grade, Sanin Sanso) was introduced. The replacement of air nitrogen gas performed twice. The needles were taken out immediately after the conclusion of gas exchange. The $120 \mathrm{ml}$ bottles were then placed in an anaerobic plastic pack (made of polyethylene, W60 $\times$ L40 $\times$ $\mathrm{H} 20 \mathrm{~cm}$, Seiko) at which point $0.5 \mathrm{ml}$ of sediment and $4.5 \mathrm{ml}$ of the bottom water sampled at the same sampling station were put into the $20 \mathrm{ml}$ vial while flushing with nitrogen gas. sodium sulfate [ $\left.{ }^{35} \mathrm{~S}\right] 1 \mu \mathrm{Ci}$ (E.I. du pont de Nemours \& Co.) was added to the sample with $1 \mathrm{ml}$ syringe.

The samples were incubated for $24 \mathrm{~h}$ at the same temperature of St. 4 (center of Lake Nakanoumi). After incubation, $1 \mathrm{ml}$ of conc. $\mathrm{HCl}$ was added to the sample by syringe. $\mathrm{H}_{2}{ }^{35} \mathrm{~S}$ was absorbed by filter paper dipped in $1 \mathrm{~N}$ zinc acetate. Absorption time used was $24 \mathrm{~h}$. Then the $7 \mathrm{ml}$ vial was taken out of the bottle and $6 \mathrm{ml}$ of sintizol (Amersham ACS II ) was added and stirred vigorously by voltex mixer (Scientific Industries). The radio activity of $\left[35_{S}\right]$ was determined by a scintillation counter (Aloka LSC-700).

Correction factor for quenching and self-adsorption by the filter paper wicks was determined to be 1.56 after the sulfur balance experiment using $\mathrm{Na}_{2}{ }^{35} \mathrm{~S}$.

\section{SO.}

The So4 concentrations in bottom and pore waters were determined by the turbidometric method according to Methods for Examination of Sewage (Japan Sewage Works Association, 1984)

\section{Temperature and salinity}

Salinity and temperature were measured on site using the salinity and temperature meter (bridge type MC5, Kent).

\section{Oxidation reduction potential (Eh)}

The probe of oxidation reduction potential was inserted into the core sample ( $\phi 2.4 \mathrm{~cm} \times \mathrm{L} 30 \mathrm{~cm})$ and the potential was determined every $\mathrm{cm}$ from the surface to a sediment depth of $5 \mathrm{~cm}$.

\section{Ignition loss and $\mathrm{COD}_{\mathrm{Mn}}$}

Ignition loss in sediment and CODMn in bottom water were determined accrding to Methods for examination of Sewage described before. 
TOC

TOC in pore water was determined by TOC analizer (Shimazu 500 ).

\section{Addition of organic matter}

The organic matter such as acetate, propionate or lactate (as sodium salt) was added to the sample in order to determine the effect of the organic matter on sulfate reduction rate. The concentration of added organic matter was $20 \mathrm{mmol} \cdot 1^{-1}$.

\section{Results}

\section{Seasonal and vertical sulfate reduction rates}

Seasonal and vertical sulfate reduction rates in the upper $5 \mathrm{~cm}$ of sediment were determined every month from September 1984 to November 1985 at the central position (St. 4) and Yonago Bay (St.
11) in Lake Nakanoumi as in shown in Fig. 3 and Fig. 4 respectively. The sulfate reduction rates in sediment of St. 4 at the depth of 0-1 cm from January to April were lower than $25 \mathrm{nmol}$ day ${ }^{-1}, \mathrm{ml}^{-1}$ while they increased to higher than $200 \mathrm{nmol} \mathrm{day}^{-1} \mathrm{ml}$ ${ }^{-1}$ in October, 1984 and September, 1985.

The maximum rates were generally observed at the surface $(0$ $1 \mathrm{~cm}$ ) of the sediment. However, the sulfate reduction at the depth of 1-3 cm was at maximum from December, 1984 to June 1985. This was due to oxic condition at the surface of the sediment in these seasons. The sulfate reduction rates decreased despending upon the depth, which were almost always lower than $25 \mathrm{nmol}$. day ${ }^{-1} \mathrm{ml}^{-1}$ at the depth of 4-5 in all seasons.

The sulfate reduction rates at St. 11, which was the most heavily polluted in Lake Nakanoumi, were relatively higher than those at St. 4. The rates at the depth of $0-1 \mathrm{~cm}$ were almost always higher than $100 \mathrm{nmol} \cdot$ day $^{-1} \mathrm{ml}^{-1}$ except for February and March. The

\section{Sulfate reduction rate $\left(\mathrm{nmol} \cdot \mathrm{day}^{-1} \cdot \mathrm{ml}^{-1}\right)$}

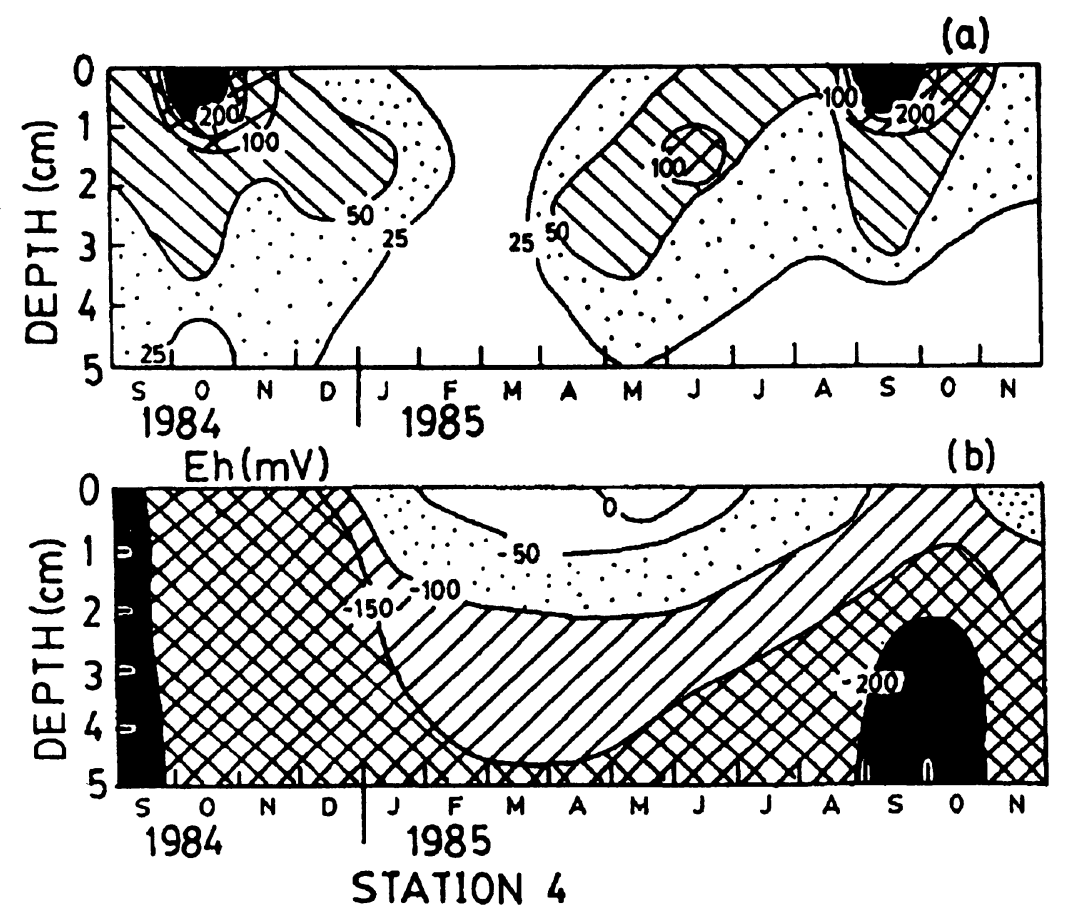

Fig. 3, Seasonal and vertical profile of sulfate reduction rates (a) and Eh (b) at St. 4.

high sulfate reduction rates greater than $200 \mathrm{nmol} \mathrm{day}^{-1} \cdot \mathrm{ml}^{-1}$ were observed in Seprember, 1984 and May, September and November, 1985.

The sulfate reduction rates at St. 11 decreased depending on the depth and were almost always lower than $25 \mathrm{nmol} \cdot$ day $^{-1} \cdot \mathrm{ml}^{-1}$ at the depth of $4-5 \mathrm{~cm}$.
Since the sulfate reduction activity was mainly observed within the surface reduction rates of the sediment in Lake Nakanoumi, the sulfate reduction rates of the upper $3 \mathrm{~cm}$ sediment were determined every month at St. 4 and st. 11, the average of which was $53.8+25$. 0 and $104.4+72.1 \mathrm{nmol} \cdot \mathrm{day}^{-1} \mathrm{ml}^{-1}$, respectively, as shown in Table 1. 


\section{Sulfate reduction rate $\left(\mathrm{n} \mathrm{mol} \cdot \mathrm{day}^{-1} \cdot \mathrm{ml}^{-1}\right)$}
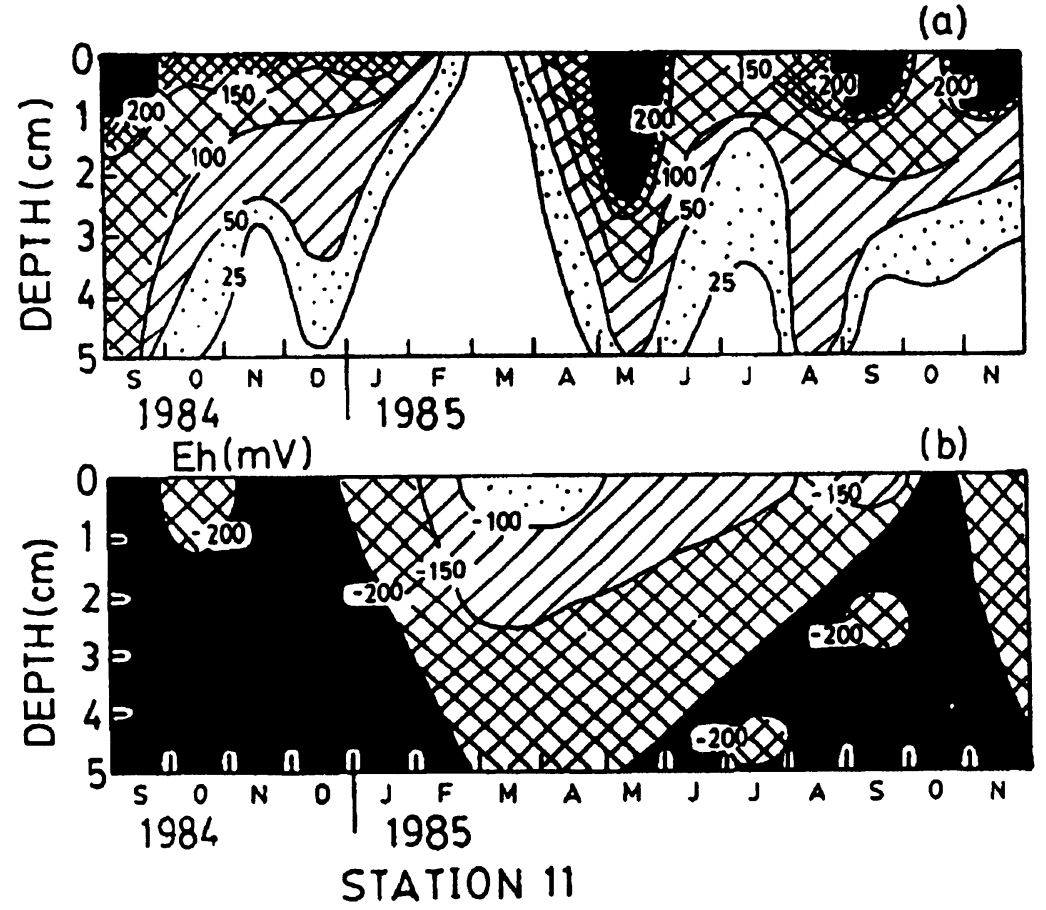

Fig. 4, Seasonal and vertical profile of sulfate reduction rates (a) and Eh (b) at St. 11.

Table 1, Effect of temperature on sulfate reduction rate of sediment sampled at St. 4 in December, 1986.

\begin{tabular}{cc}
$\begin{array}{c}\text { Temperature } \\
\text { C }\end{array}$ & $\begin{array}{c}\text { sulfate reduction rate } \\
\text { nmol. } \text { ml }^{-1} \text {. day }\end{array}$ \\
\hline 5 & 2 \\
15 & 21 \\
25 & 57 \\
\hline
\end{tabular}

\section{Temperature}

Jøgensen (1977) found the temperature coefficients ( $\left.Q_{10}\right)$ of 3.0 between $0^{\circ} \mathrm{C}$ and $30^{\circ} \mathrm{C}$ in the sediments from Limfjorden. He stated that the SRB had a temperature regulation of their metabolic rate comparable to that of heterotrophic organisms. Table 1 shows that the sulfate reduction rate of the sediment in Nakanoumi at the depth of $0-1 \mathrm{~cm}$ at $25^{\circ} \mathrm{C}$ was approximately twice as high as that at $15^{\circ}$. It, therefore, can be said that this reaction between $15^{\circ}$ and $25^{\circ} \mathrm{C}$ followed the $Q_{10}$ law. The sulfate reduction rate, however, was quite low at $5^{\circ} \mathrm{C}$ because the activity of SRB should be low at this temperature. Postqate (1984) said that most mesophilic SRB are grown at $30^{\circ}$ and most thermophiles at $55^{\circ} \mathrm{C}$, but these quidelines were not rigid.

The changes of temperatures in the bottom water of St. 4 are indicated in Fig.5. The temperature rose to about $25^{\circ} \mathrm{C}$ in summer and early autumn, though it went down to $8^{\circ} \mathrm{C}$ in winter.

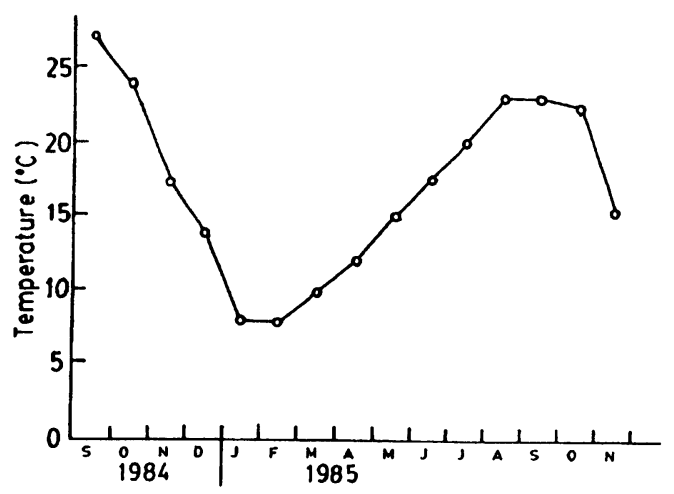

Fig. 5, Changes in temperature in the bottom water of St. 4.

Being greatly influenced by the temperature, the sulfate reduction rates in winter were relatively lower than those in another seasons.

However, the sulfate reduction rates did not necessarily depend on the temperature. As shown in Fig. 4, the high sulfate reduction was obtaind in May and November when the temperatures were about $15^{\circ} \mathrm{C}$. This implies that there would be other factors which affect sulfate reduction rates besides temperature. 


\section{Organic matter}

There was little difference between the ignition loss the sediments at St.4 and St.11, which were15.3+0.7and $16.1+1-1 \%$, respectively. On the other hand, the average of TOC $(n=3)$ in the pore water of the sedimate $(0-3 \mathrm{~cm})$ at St. 11 from January to March, 1985 was $24.8 \mathrm{mg} \cdot 1^{-1}$, which was higher than that at St. 4 $\left(18.2 \mathrm{mg} \cdot 1^{11}\right)$.

The annual average concentration of CODma of St. 11 in the bottom water was $2.5 \mathrm{mg} \cdot 1^{-1}$, which was higher than that of St. 4, $1.5 \mathrm{mg} \cdot 1^{-1}$. It can be assumed from these results that sulfate reduction rates might be affected by dissolved organic matter in pore and/or bottom waters.

Fig.6 shows the effect of organic matter addition on the sulfate reduction rate. The addition of lactate, acetate and propionate stimulated the sulfate reduction rate, which was greatly affected in the case of lactate.

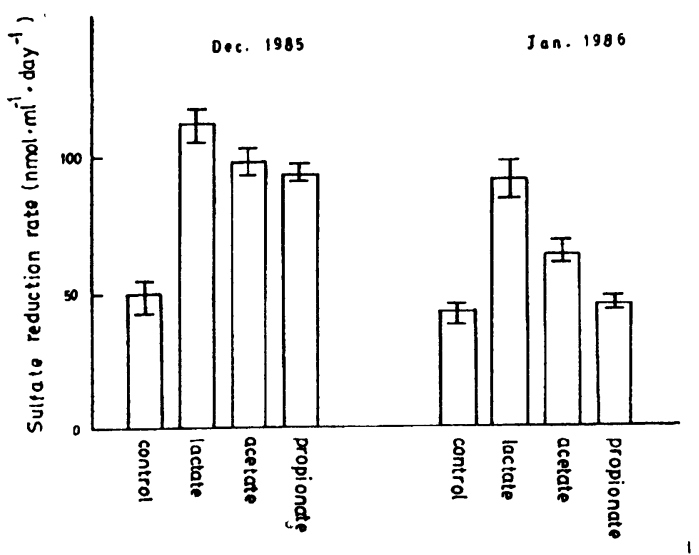

Fig. 6, Effect of fatty acid addition on sulfate reduction rate of sediments collected from St. 11 .

It can be said from this result that organic matter is limiting material for sulfate reduction at St. 11 and there should exist sulfate reducing bacteria which utilize these fatty acids. Sulfate dose not seem to be limiting factor because its concentration in pore water in Sts 4 and 11 ranged from 9-28 and 11-18 $\mathrm{mmol}^{-1}$, respectively.

\section{Oxygen reduction potential (Eh)}

The seasonal Eh values of the sediments collected from Sts. 4 and 11 are shown in Figs. $3 \mathrm{~b}$ and $4 \mathrm{~b}$, respectively.

Eh of the sediments of St. 4 at the depth of $0-2 \mathrm{~cm}$ from September to December, 1984 and from September to October, 1985 was lower than $-100 \mathrm{mV}$. The sulfate reduction rates of the sediments during these months were higher than $50 \mathrm{nmol} \mathrm{day}^{-1} \mathrm{ml}$ ', which were especially high in October, 1984 and November, 1985, greater than $200 \mathrm{nmol}_{\text {. day }}^{-1}$. $\mathrm{ml}^{-1}$.

When Eh of the sediments at the depth of $0-2 \mathrm{~cm}$ rose to qreater than $-50 \mathrm{mV}$ from February to June, 1985, the sulfate reduction rates during these months were almost always loways lower than
$50 \mathrm{nmol}^{\cdot} \cdot$ day $^{-1} \cdot \mathrm{ml}^{-1}$.

The Eh values of the sediments at the depth of $0-2 \mathrm{~cm}$ collected from St. 11 are lower than those St. 4, which were almost always lower than $-150 \mathrm{mv}$ from September, 1984 to January, 1985. The sulfate reduction rates of the samples during these months were greater than $150 \mathrm{nmol} \cdot$ day $^{-1} \cdot \mathrm{ml}^{-1}$.

As described before, the sulfate reduction rates did not necessarily depend on the temperature. But the sulfate reduction rates of the sediment at the depth of $0-2 \mathrm{~cm}$ closely depended upon $\mathrm{Eh}$, that is, which rose when Eh went down to lower than approximately $-100 \mathrm{mV}$.

However, the sulfate reduction rates of sediments below $2 \mathrm{~cm}$ were quite low compared with those of upper $2 \mathrm{~cm}$ though Eh was always lower than $-100 \mathrm{mV}$ and $-150 \mathrm{mV}$ at Sts. 4 and 11 . respectively. This reason was not clarified yet, but might be due to the shortage of organic matter at the depths below $2 \mathrm{~cm}$ because the supply of organic matter would be limited at the deeper depth.

The sulfate reduction rate of the sediment at the depth of $0-2 \mathrm{~cm}$ in May, 1985 marked the highest value $502 \mathrm{nmol} \cdot$ day $^{-1} \cdot \mathrm{ml}^{-1}$ though Eh was $-110 \mathrm{mV}$ and the temperature was $15^{\circ} \mathrm{C}$.

This reason might be due to the elevation in the activity of SRB with a rise temperature.

\section{Discussion}

The average sulfate reduction rate of upper $3 \mathrm{~cm}$ sediments at Sts. 4 and 11 were 53.8 and $104.4 \mathrm{nmol} \mathrm{day}^{-1} \mathrm{ml}^{-1}$, respectively. Since $1 \mathrm{~mol}$ of sulfate oxidized twice as much organic carbon to $\mathrm{CO}_{2}$ (J $\phi$ rgensen 1977, Howarth \& Teal 1979), the decomposition rate of carbon can be calculated stoichiometriclly. Therefore, the annual average decomposition rate of organic carbon in the sediment of Sts. 4 and 11 are determined to be 14.2 and $27.4 \mathrm{~g} \mathrm{~m}^{-2}$, respectively. The decomposition rate of organic matter in a coastal marine sediment (Limfjorden) and salt marsh were 84 (Jørgensen 1977) and $1800 \mathrm{~g} \cdot \mathrm{m}^{-2} \cdot \mathrm{y}^{-1}$ (Howarth \& Teal 1979), respectively.

The decomposition rate of the sediment in Lake Nakanoumi is in the same order of magnitude as that in Limfjorden, but further lower than that in salt marsh. This might be due to the amount of organic matter and other environmental factors.

It is of importance to determine what kinds of organic matter are utilized by SRB. In this paper, there appeared an effect of addition of lactate, propionate or acetate on the sulfate reduction rate of the sediment at St. 11. It is, therefore, estimated that there existed SRB which utilize these fatty acids. But, it is clarified yet that such organic matter are produced or not in the sediment o the lake Nakanoumi. Further study is necessary on the mechanism of the production of organic matter from sediment and the relationship between the growth of SRB and the supply of fatty acids.

J $\phi$ rgensen (1977) and Hawarth \& Teal (1979) assumed that lactate was utilized by SRB. On the other hand, the new SRB which utilize acetate as a sole carbon source were found (Widdel \& Pfennig 1981). Sorensen et al. (1981) reported that acetate was a major substrate for the SRB in the sediment of a shallow coastal lagoon and might account for $50 \%$ of the electron donors for the 
sulfate reduction process and other electron donors were propionate, butylate and hydrogen.

Balba and Nedwell (1982) started that carbon flow through the acetate pool was far greater than that through either propionate, butylate in surface sediment of a salt marsh.

Sansone and Martens (1982) also said that the concentration and turnover rate of acetate were greatly lager than those of propionate, butyrate or isobutyrate.

The enzymatic mechanism of acetate oxidation by SRB also has been investigated (Brandis-Heep et al. 1983 and Gebhardt et al. 1983).

\section{Aeknowledgements}

We are grateful for the assistance of the sampling by the office of the Nakanoumi Reclamation Project, Ministry of Agriculture, Forestry and Fishing of Japan.

\section{References}

Balba, M.T. and D.B.Nedwell, 1982. Microbial metabolism of acetate, propionate and butylate in anoxic sediment from the Colne Point Saltmarsh, Essex, U,K., Journal General Microbiology. 128 : 145-1422

Banat,I.M.,Nedwell,D.B. \& M.T.Balba, 1983. Stimulation of methanogenesis by slurries of salt marsh sediment after the addition of molybdate to inhibit sulphate-reducing bacteria. Journal General Microbiology. 129 : 123-129.

Brandis-Heep,A.,Gebhardt,N.A,Thauer,R.K., Widdel,F. \& N. Pfenning, 1983. Anaerobic acetate oxidation to $\mathrm{CO}_{2} \mathrm{p}$ by

Desulfobacter postagatei 1 . Demonstration of all enzymes required for the operation of the Citric acid cycle.Arch Microbiol. 136 : 222-229

Gebhardt, N.A.,Linder,D. \& R.K.Thaner, 1983. Anaerobic acetate oxidation to $\mathrm{CO}_{2}$ by Desulfobacter postgatei 2 . Evidence from ${ }^{14} \mathrm{C}$-labelling studies for the operation of the citric cycle. Arch Microbiol. 136 : 230-233.

Hines,M.E. \& J.D.Buck, 1982. Distribution of methanogenic and sufate-reducing bacteria in near-shore marine sediments. Appl Environ Microbiol. 43 : 447-453.

Hawarth R.W. \& J.M.Teal,1979. Sulfate reduction in a New England salt marsh Limnol. Oceanogr. 24,999-1013.

Japan Sewage Works Association, 1984. Methods for examination of Sewage, 172-173. Japan Sewage Works Association, Tokyo

. Jorgensen,B.B,.1977. The sulfer cycle of a coastal marine sediment (Limfjorden, Denmark). Limnology and Oceanography, 22, 814-832.

Kristjansson,J.K., Schonheit, P. \& R.K.Thauer, 1982. Different Ks values for hydrogen of methanokgenic bacteria and sulfate reducing bacteria : an explanation for the apparent inhibition of methanogenesis of sulfate. Arch Microbiol. $131: 278-282$.

Laanbroek,H.J. \& N.Pfennig, 1981. Oxidation of shout-chain fatty acids by sulfate-reducing bacteria in freshwater and in marine sediments. Arch Microbiol. 128 : 330-335.

Mori,T., H.Ohtake, K.Kondo, Y.Seike \& Y.Date, 1987. Significance of a halocline to nutrient cycles in shallow brackish Lake Nakanoumi, Japan. Hydrobiologia. 146 : 181-186.

Munson,D.A. 1977. Simplified method for the determination of acid-solble sulfides in marine sediments, Marine Biology. 40 : 145-150.

Ohtake,H., Kondo,K., Seike,I \& Y.Date, 1982. Seasonal and areal featuresof the lagoonal environment in Lake Nakanoumi, a shallow coastal lagoon in Japan. Hydrobiologia 97 : 15-26.

Ohtake, H., Kato,S. \& Y. Date, 1984. The role of tides in removing phosphorus from Lake Nakanoumi, a coastal lagoon in Japan. Arch. Hydrobiol. 99 : 443-462.

Postgate,J.R.,1984. The sulphate reducing bacteria, second edition,p34 Cambridge University Press, Cambridge.

Robinson,J.A \& J.M.Tiedje, 1984. Competition between sulfate-reducing and methanogenic bacteria for $\mathrm{H}_{2}$ under resting and growing conditions, Arch Microbiol. 137 : 26-32.

Rosser,H.R, \& W.A.,Hamilton, 1983. Simple assay for acculate determination of $[35 \mathrm{~S}]$ sulfate reduction activity. Appl Environ, Microbiol. 45 : 1956-1959.

Sanson, F.J, \& C.S.Martens, 1982. Volatile fatty acid cycling in organic-rich marine sediments, Geochimica et Cosmochimica Acta. 46 : 1575-1589.

Satake,K., 1983. A small handy corer for sampling of lake surface sediment, Jap J Limnol. 44 : 142-144.

Schonheit,P., Kristjansson,J.K \& R.K.Thaner, 1982. Kinetic mechanism for the ability of sulfate reducers to out-compate methanogens for acetate. Arch Microbiol. 132 : 28.5-288.

Sorensen,J., Christensen,D. \& B.B.Jorgensen, 1981. Volatile fatty acids and hydrogen as substrates for sulfate reducing bacteria in anarobic marine sediment. Appl. environ. microbiol. 42 : $5-11$.

Widdel,F. \& N.Pfenning, 1981. Studies in dissimilatory sulfatereducing bacteria that decompose fatty acids. 1.Isolation of new sulfate-reducing bacteria enriched with acetate from saline enviroments. Description of Desulfobacter postgatei gen. nov.,sp. nov. Arch Microbiol. 131 : 360-365.

Winfrey,M.R. \& D.M.Ward,1983. Substrates for sulfate reduction and methane production in intertidal sediments. Appl Environ Microbiol. 45 : 193-199. 